\title{
PENGARUH FAKTOR-FAKTOR PERILAKU KONSUMEN TERHADAP KEPUTUSAN MENGINAP
}

\author{
Nidia Wulansari ${ }^{1}$, Youmil Abrian ${ }^{2}$, Arif Adrian ${ }^{3}$ \\ ${ }^{1,2,3)}$ Prodi Manajemen Perhotelan, Fakultas Pariwisata dan Perhotelan, Universitas Negeri Padang \\ e-mail: nidia.wulansari@fpp.unp.ac.id ${ }^{1)}$, abrian.yomil@gmail.com ${ }^{2)}$, arifadrianse@gmail.com ${ }^{3)}$
}

\begin{abstract}
Abstrak
Kota Bukitinggi menjadi salah satu tujuan wisata bagi wisatawan yang datang ke Sumatera Barat. Dengan adanya daya tarik wisata, seperti wisata alam, kuliner dan sejarah dapat meningkatkan kunjungan ke Bukittinggi. Meningkatnya kunjungan berimbas pada meningkatnya kebutuhan sarana akomodasi, seperti hotel. Fenomena menarik dalam penelitian ini adalah hotel bintang empat yang berada di Bukittinggi selalu mengalami peningkatan occupancy (tingkat hunian) menuju akhir tahun. Walaupun harga kamar yang ditawarkan relatif tinggi dibandingkan dengan hotel lain yang berada di Buktitinggi. Tujuan penelitian ini adalah untuk menganalisis pengaruh faktor perilaku konsumen terhadap keputusan menginap pada hotel bintang empat Kota Bukittinggi. Jenis penelitian ini adalah asosiatif kausal yang mengetahui pengaruh masing-masing faktor perilaku konsumen terhadap keputusan menginap Populasi dalam penelitian ini adalah tamu yang pernah menginap di hotel bintang empat Kota Bukittinggi, dengan jumlah sampel 125 orang dengan menggunakan teknik purposive sampling. Teknik analisis data yang digunakan adalah analisis regresi linier berganda dengan menganalisis pengaruh faktorfaktor perilaku konsumen terhadap keputusan menginap tamu, baik secara bersama-sama (simultan) maupun pengaruh masing-masing faktor (parsial). Hasil penelitian menunjukkan bahwa: Faktor-faktor perilaku konsumen yaitu faktor budaya, faktor sosial, faktor pribadi dan faktor Psikologis berpengaruh signifikan terhadap keputusan menginap. Faktor budaya tidak berpengaruh signifikan terhadap keputusan tinggal.
\end{abstract}

Kata kunci: Perilaku Konsumen, Keputusan Menginap, Hotel

\begin{abstract}
Bukitinggi is one of the common and popular tourist destinations in West Sumatra. With the existence of tourist attractions, such as natural, culinary and historical tourism, can increase the tourism visits to Bukittinggi. The increase in visits has an impact on the increasing need for accommodation facilities, especially for hotels. An interesting phenomenon in this study is that four-star hotels in Bukittinggi always experience an increase in occupancy towards the end of the year. Although the price of the rooms offered is relatively high compared to other hotels in bukittinggi. The purpose of this study was to analyze the influence of consumer behavior factors on guest stay decisions at four-star hotels in Bukittinggi. This type of research is a causal associative that determine the effect of each factors of consumer behavior on guest stay decisions at four-star hotels in Bukittinggi. The population in this study were guests who had stayed at the four-star hotel Bukittinggi, with the total sample were 125 people by using purposive sampling technique. Data analysis technique used was multiple linear regression analysis by analyze the influence of consumer behavior factors on guest stay decisions, both together (simultaneously) and the influence of each factor (partial). The results showed that: The factors of consumer behavior, namely cultural factors, social factors, personal factors and Psychological factors significantly influence on the decision to stay. Cultural factors do not significantly influence the decision to stay.
\end{abstract}

Keywords: Consumer Behavior, Staying Decision, Hotel 


\section{PENDAHULUAN}

Provinsi Sumatera Barat terkenal dengan pariwisata, kebudayaan dan kesenian. Salah satu kota yang terkenal dengan pariwisata, kebudayaan dan kesenian adalah Kota Bukittinggi. Kota ini merupakan tujuan wisata bagi para turis lokal maupun mancanegara. Kota Bukittinggi memberikan pengalaman menarik bagi turis yang datang ke tempat ini karena menawarkan banyak tempat wisata, mulai dari wisata alam, wisata belanja, wisata kuliner, dan wisata sejarah. Selain itu, destinasi wisata yang saling berdekatan dan mudah untuk diakses adalah salah satu keunggulan Kota Bukittinggi. Sebut saja, salah satu wisata yang menjadi iconic kota ini adalah "Jam Gadang Bukttinggi". Hal ini menjadi daya tarik sehingga meningkatkan kunjungan wisatawan ke Kota Bukittinggi. Menurut Putra et al (2019) keunikan dan kekhasan suatu objek wisata merupakan potensi yang dapat dikembangkan dan dipromosikan untuk menarik minat wisatawan berkunjung ke objek wisata tersebut. Dengan meningkatnya kunjungan wistawan maka kebutuhan sarana akomodasi juga meningkat. Salah satu sarana akomodasi yang berkembang di Kota Bukittingi adalah penyedian jasa hotel. Hotel menjadi kebutuhan yang penting bagi wisatawan apabila berkunjung ke suatu daerah ataupun suatu negara sebagai tempat beristirahat.

Terdapat tiga hotel bintang empat yang berada Bukittinggi yaitu Grand Royal Denai, Grand Rocky Hotel dan Novotel Bukittinggi. Tingkat hunian kamar (occupancy) dari ketiga hotel tersebut selalu meningkat. Data occupancy dapat dilihat pada tabel berikut:

Tabel 1. Occupancy Hotel Bintang 4 Bukittinggi Periode Oktober-Desember 2018

\begin{tabular}{lllll}
\hline No & Bulan & Grand Royal Denai & Grand Rocky & Novotel \\
\hline 1 & Oktober & $47.95 \%$ & $75.35 \%$ & $82.52 \%$ \\
\hline 2 & November & $62.63 \%$ & $77.01 \%$ & $89.01 \%$ \\
\hline 3 & Desember & $65.19 \%$ & $85.58 \%$ & $93.98 \%$ \\
\hline
\end{tabular}

Fenomena menarik dalam penelitian ini adalah ketiga hotel bintang empat tersebut selalu mengalami peningkatan occupancy (tingkat hunian) menuju akhir tahun yaitu bulan Oktober, November dan Desember. Akan tetapi, konsumen selalu memilih ketiga hotel tersebut untuk menginap, walaupun harga kamar yang ditawarkan relatif tinggi dibandingkan dengan hotel lain yang berada di buktitinggi. Padahal ketiga hotel tersebut menerapkan kebijakan kenaikkan harga kamar setiap periodenya. Jika dilihat dari harga, terdapat perbedaan yang cukup signifikan antara harga hotel bintang empat dengan hotel bintang tiga maupun jasa penginapan lainnya di Kota Bukittinggi. Bahkan perbedaan harga kamar juga terlihat sangat jauh berbeda dengan hotel berbintang empat yang ada di pusat ibu kota Sumatera Barat, Padang.

Berdasarkan hal tersebut, peneliti tertarik untuk melihat faktor perilaku konsumen terhadap keputusan menginap di hotel bintang empat di Kota Bukittinggi. Menurut Hasan (2013), perilaku konsumen adalah studi proses yang terlibat ketika individu atau kelompok memilih, membeli, menggunakan, atau mengatur produk, jasa, idea atau pengalaman untuk memuaskan kebutuhan dan keinginan konsumen. Menurut kottler dan keller (2012), faktor-faktor yang mempengaruhi perilaku konsumen yaitu budaya, sosial, pribadi dan psikologis. Pengaruh budaya dapat mempengaruhi masyarakat secara tidak sadar. Pengaruh budaya sangat alami dan otomatis sehingga pengaruhnya terhadap perilaku sering diterima begitu saja. Faktor sosial berarti berkaitan antara manusia dengan masyarakat, hubungan manusia dengan kelompok, dan hubungan manusia dengan 
organisasi. Perilaku konsumen juga dipengaruhi oleh karakteristik pribadi, dimana di dalamnya termuat usia, tahap siklus hidup, pekerjaan, dan keadaan. Terakhir, perilaku konsumen dipengaruhi oleh faktor psikologis yang terdiri dari motivasi, persepsi dan pengetahuan. Dengan mempelajari faktor yang mempengaruhi perilaku konsumen dapat menimbulkan gagasan mengenai strategi yang tepat agar penjualan maksimal dan menjadi acuan bagi para pemasar untuk mengembangkan produk.

Persaingan bisnis hotel di Kota Bukittinggi menyebabkan para konsumen memiliki berbagai macam pilihan hotel dengan harga serta fasilitas yang juga bervariatif. Dengan mengetahui faktor-faktor yang mendorong keputusan konsumen bermalam di suatu hotel akan mempermudah pihak pengelola hotel dalam menentukan langkah-langkah dan menerapkan strategi pemasaran yang tepat sehingga pada akhirnya hal tersebut dapat semakin meningkatkan hunian hotel.

Dari latar belakang masalah yang telah dikemukakan maka penulis memilih judul penelitian sebagai berikut: Pengaruh Faktor-Faktor Perilaku Konsumen Terhadap Keputusan Menginap

\section{KAJIAN PUSTAKA / KAJIAN TEORI}

\subsection{Perilaku Konsumen}

Kotler dan Keller (2012), pemasaran adalah suatu proses sosial yang didalamnya individu maupun kelompok untuk mendapatkan apa yang mereka butuhkan dan inginkan dengan menciptakan, menawarkan, dan secara bebas mempertukarkan produk yang bernilai dengan pihak lain. Definisi tersebut menggambarkan bahwa titik tolak dari kegiatan pemasaran terletak pada kebutuhan dan keinginan manusia yang beraneka ragam.

Faktor-faktor yang mempengaruhi perilaku konsumen

\section{Faktor Budaya}

Kottler dan Keller (2012), budaya adalah kumpulan nilai-nilai dasar, persepsi, keinginan dan tingkah laku yang dipelajari oleh seorang anggota masyarakat dari keluarga dan lembaga penting lainnya. Budaya merupakan faktor penentu keinginan dan perilaku seseorang yang paling mendasar.

2. Faktor Sosial

Pengertian sosial pada strukturnya, yaitu suatu tatanan dari hubungna-hubungan sosial dalam masysrakat yang menempatkan pihak-pihak tertentu (keluarga, kelompok, dan peran ) dalam posisi-posisi tertenti berdasarkan suatu sistem nilai dan norma yang berlaku pada suatu masyarakat pada waktu tertentu.

3. Faktor Pribadi

Faktor pribadi didefinisikan sebagai karakteristik psikologis seseorang yang berbeda dengan orang lain yang menyebabkan tanggapan yang relatif konsisten dan bertahan lama terhadap lingkungan.

4. Psikologis

Kottler dan keller (2012), faktor psikologis sebagai bagian dari pengaruh lingkungan dimana ia tinggal dan hidup pada waktu sekarang tanpa mengabaikan pengaruh dimasa lampau atau antisipasinya pada waktu yang akan datang, pilihan barang yang dibeli seseorang lebih lanjut dipengaruhi oleh faktor psikologi. Tugas pemasan adalah memahami apa yang terjadi dalam kesadaran konsumen antara datangnya rangsangan pemsaran luar dan keputusan pembelian akhir 
Faktor-Faktor yang Mempengaruhi Perilaku Konsumen dalam Melakukan Pembelian :

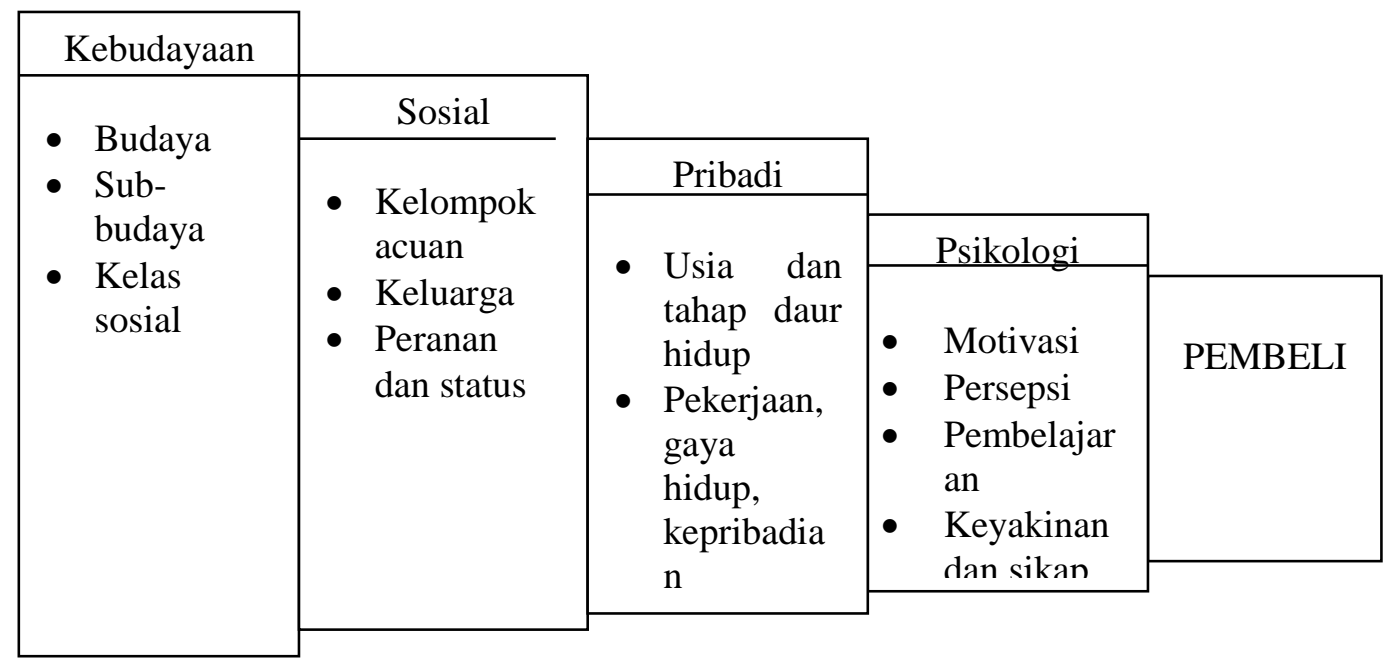

Gambar 1. Faktor-Faktor yang Mempengaruhi Prilaku Konsumen

Sumber: Kotler, 2012

\subsection{Keputusan Pembelian}

Tjiptono (2008) menyatakan berdasarkan tujuan pembelian konsumen dapat diklasifikasikan menjadi tujuan pembeliannya adalah untuk memenuhi kebutuhan sendiri sedangkan konsumen organisasional tujuannya untuk keperluan bisnis.

a. Pengenalan kebutuhan

Proses membeli dimulai dengan pengenalan masalah dimana pembeli mengenali adanya masalah atau kebutuhan. Pembeli merasakan perbedaan antara keadaan nyata dan keadaan yang diinginkan.

b. Pencarian Informasi

Seorang konsumen yang sudah terkait mungkin mencari lebih banyak informasi tetapi mungkin juga tidak. Bila dorongan konsumen kuat dan produk yang dapat memuaskan ada dalam jangkauan, konsumen kemungkinan akan membelinya bila tidak, konsumen dapat menyimpan kebutuhan dalam ingatan atau melakukan pencarian informasi yang berhubungan dengan kebutuhan tersebut.

Evaluasi alternatif

Tahap dari proses keputusan membeli, yaitu ketika konsumen menggunakan informasi untuk mengevaluasi merek alternatif dalam perangkat pilihan. Konsep dasar tertentu membantu menjelaskan proses evaluasi konsumen. Pertama, kita menganggap bahwa setiap konsumen melihat produk sebagai kumpulan atribut produk. Kedua, konsumen akan memberikan tingkat arti penting berbeda terhadap kebutuhan dan keinginan unik masing-masing. Ketiga, konsumen mungkin akan mengembangkan satu himpunan keyakinan merek mengenai dimana posisi setaip merek pada setiap atribut. Keempat, harapan kepuasan produk total konsumen akan bervariasi pada tingkat atribut yang berbeda. Kelima, konsumen sampai pada sikap terhadap merek berbeda lewat beberapa produser evaluasi.Ada konsumen yang menggunakan lebih dari satu prosedur evaluasi, tergantung pada konsumen dan keputusan pembelian. 
c. Keputusan pembelian

Dalam tahap evaluasi, konsumen membuat peringkat merek dan membentuk niat untuk membeli.Pada umumnya, keputusan membeli konsumen adalah membeli merek yang paling disukai, tetapi dua faktor dapat muncul antara niat untuk membeli dan keputusan untuk membeli.Faktor pertama, adalah sikap orang lain, yaitu sikap dari orang lain mengenai harga, merek yang akan dipilih konsumen. Faktor kedua, adalah faktor situasi yang tidak diharapkan, harga yang diharapkan dan manfaat produk yang diharapkan.Akan tetapi peristiwa-peristiwa yang tidak diharapkan bisa menambah niat pembelian.

d. Tingkah laku pasca pembelian

Tahap dari proses keputusan pembeli, yaitu konsumen mengambil tindakan lebih lanjut setelah membeli berdasarkan pada rasa puas atau tidak puas.

Hipotesis yang diajukan adalah sebagai berikut:

H1: Faktor budaya, sosial, pribadi, dan psikologis berpengaruh terhadap keputusan menginap.

H2: Faktor budaya diduga berpengaruh terhadap keputusan menginap.

H3: Faktor sosial diduga berpengaruh terhadap keputusan menginap.

H4: Faktor pribadi diduga berpengaruh terhadap keputusan menginap.

H5: Faktor psikologis diduga berpengaruh terhadap keputusan menginap.

\section{METODE PENELITIAN}

Berdasarkan permasalahan dan tujuan yang ingin dicapai, jenis penelitian ini digolongkan kepada penelitian asosiaif kausal. Suryabrata (2012) menjelaskan bahwa; "Penelitian asosiatif kausal adalah penelitian yang bertujuan untuk menyelidiki kemungkinan hubungan sebab akibat dengan cara pengamatan terhadap akibat yang ada mencari kembali faktor yang mungkin menjadi penyebab melalui data tertentu". Variabelvariabel yang terlibat dalam penelitian ini adalah Variabel bebas yaitu faktor-faktor prilaku konsumen yaitu Budaya (X1), Sosial (X2), Pribadi (X3) dan Psikologi (X4) serta Variabel terikat berupa keputusan pembelian jasa kamar di Hotel Bintang 4 Bukittinggi (Y).

Populasi dalam penelitian ini adalah seluruh konsumen yang pernah menginap di hotel bintang empat bukittinggi. Jumlah sampel yang digunakan dalam penelitian ini disesuaikan dengan metode analisis yang digunakan yaitu Regresi linear berganda. Menurut Ferdinand (2013) menyatakan bahwa bila ukuran sampel terlalu besar maka model menjadi sangat sensitif sehingga sulit untuk mendapatkan goodness of fit yang baik. Sehingga, jumlah sampel yang dibutuhkan paling sedikit 5 kali jumlah variabel indikator (Ferdinand, 2013). Adapun jumlah indikator dalam penelitian ini sebanyak 25 indikator, sehingga minimal dibutuhkan 25 x 5 atau 125 sampel.

Dalam menentukan sampel, peneliti menggunakan non-probablity sampling karena tidak memberi peluang/kesempatan yang sama bagi setiap anggota populasi untuk menjadi sampel (Sugiyono, 2013). Metode pengambilan sampel dalam penelitian ini adalah purposive sampling. Metode purposive sampling merupakan metode pengambilan sampel yang dilakukan berdasarkan kriteria yang telah ditentukan oleh peneliti (Ferdinand, 2013). Adapun kriteria konsumen/ tamu yang akan dijadikan sampel dalam penelitian ini adalah konsumen yang sudah pernah menginap di hotel bintang empat Bukittinggi. Berikut ini operasional variabel penelitian: 
Tabel 2. Operasional variabel penelitian

\begin{tabular}{|c|c|}
\hline Variabel & Indikator \\
\hline \multirow[t]{3}{*}{ Budaya (X1) } & 1. Perkembangan dan kemajuan budaya \\
\hline & 2. Kesamaan budaya \\
\hline & 3. Jenis suku/ ras \\
\hline \multirow[t]{4}{*}{ Sosial (X2) } & 1. Keberadaan teman untuk memilih produk \\
\hline & 2. Keberadaan anggota keluarga untuk memilih produk \\
\hline & 3. Keberadaan orang tua atau orang yang dituakan untuk memilih produk \\
\hline & 4. Kelas sosial \\
\hline \multirow[t]{3}{*}{ Pribadi (X3) } & 1. Pekerjaan, \\
\hline & 2. Keadaan ekonomi /penghasilan \\
\hline & 3. Gaya hidup \\
\hline \multirow[t]{4}{*}{ Psikologis (X4) } & 1. Motivasi untuk memilih produk \\
\hline & 2. Persepsi untuk memilih produk \\
\hline & 3. Pembelajaran dari pengalaman, sehingga memilih produk \\
\hline & 4. Keyakinan terhadap produk \\
\hline Keputusan & 1. Kebutuhan terhadap produk \\
\hline \multirow[t]{3}{*}{ Menginap (Y) } & 2. Pencarian informasi terhadap produk \\
\hline & 3. Evaluasi terhadap produk \\
\hline & 4. Keputusan memilih produk \\
\hline
\end{tabular}

Teknik pengambilan data yang digunakan dalam pengumpulan data menggunakan Kuesioner, teknik pengumpulan data melalui formulir-formulir yang berisi pertanyaanpertanyaan yang diajukan secara tertulis pada seseorang atau sekumpulan orang untuk mendapatkan jawaban atau tanggapan dan informasi yang diperlukan oleh peneliti. Instrumen untuk mengumpulkan data dalam penelitian ini adalah berupa kuesioner yang disusun dengan menggunakan skala likert.

Menurut Ghozali (2016), sebelum kuesioner digunakan, terlebih dahulu dilakukan uji validitas dan uji realibitas. Hal ini untuk menentukan batas-batas kebenaran dan ketepatan alat ukur suatu indikator variabel penelitian. Selanjutnya di lakukan uji asumsi klasik yaitu uji normalitas, uji multikolinearitas, uji autokorelasi dan uji heteroskedastisitas. Teknik analisis menggunakan metode analisis regresi linear berganda yang diolah berdasarkan bantuan aplikasi SPSS.

\section{HASIL DAN PEMBAHASAN}

Uji instrumen dilakukan kepada tamu yang menginap di Grand Rocky Hotel Bukittinggi. Sedangkan sampel untuk uji coba instrumen menggunakan sampel minimum. Peneliti menggunakan sampel minimum untuk uji coba instrumen penelitian sebanyak 30 orang responden. Berdasarkan dari hasil analisis validitas mengungkapkan 30 butir pertanyaan dinyatakan valid, menggunakan analisis Korelasi Pearson. Dari hasil perhitungan analisis reliability, diperoleh nilai Alpha Cronbach untuk Faktor Budaya adalah 0.802, Faktor Sosial 0.888, Faktor Pribadi 0.844, Faktor Psikologi 0.782 dan nilai Alpha Cronbach keputusan menginap adalah 0.872. Bila nilai reliabilitas tersebut diinterprestasikan maka instrumen yang penulis gunakan tergolong sangat tinggi dan tinggi tingkat reliabilitasnya.

Selanjutnya, uji persyaratan analisis meliputi uji normalitas, uji homogenitas dan uji linieritas terhadap data penelitian. Berikut ini merupakan hasil uji normalitas yang dapat dilihat pada tabel 3 . 
Tabel 3. Hasil Uji Normalitas One-Sample Kolmogorov-Smirnov Test

\begin{tabular}{|c|c|c|c|c|c|c|}
\hline & & Budaya & Sosial & Pribadi & Psikologi & $\begin{array}{c}\text { Kep } \\
\text { Menginap }\end{array}$ \\
\hline $\mathrm{N}$ & & 125 & 125 & 125 & 125 & 125 \\
\hline \multirow{2}{*}{$\begin{array}{l}\text { Normal } \\
\text { Parameters }^{\mathrm{a}}\end{array}$} & Mean & 18,7600 & 21,7360 & 21,6720 & 23,4800 & 22,1360 \\
\hline & $\begin{array}{l}\text { Std. } \\
\text { Deviation }\end{array}$ & 4,34853 & 4,20281 & 3,95086 & 4,44065 & 4,89625 \\
\hline \multirow{3}{*}{$\begin{array}{l}\text { Most Extreme } \\
\text { Differences }\end{array}$} & Absolute & ,089 &, 117 &, 085 &, 115 &, 114 \\
\hline & Positive & ,089 &, 083 & ,078 &, 075 &, 073 \\
\hline & Negative &,- 062 &,- 117 &,- 085 &,- 115 &,- 114 \\
\hline \multicolumn{2}{|c|}{ Kolmogorov-Smirnov Z } & ,997 & 1,309 & ,951 & 1,281 & 1,275 \\
\hline \multicolumn{2}{|c|}{ Asymp. Sig. (2-tailed) } &, 273 &, 065 &, 326 &, 075 & 077 \\
\hline
\end{tabular}

Berdasarkan tabel diatas diketahui bahwa nilai Sig untuk budaya, social, pribadi, psikologi dan keputusan menginap berturut-turut adalah 0.273, 0.065, 0.326, 0.075 dan 0.077 lebih besar dari 0.05 , sehingga dapat disimpulkan bahwa data kelima variabel tersebut terdistribusi normal.

Selain itu, perhitungan uji independen antar variabel bebas dapat dilihat dari hasil analisis collinearty statistics. Untuk melihat apakah ketiga variabel bebas tidak terjadi korelasi yang tinggi, maka perlu dilakukan uji hipotesis seperti terlihat pada tabel 4 berikut:

Tabel 4. Angka VIF dan Tolerance

\begin{tabular}{llcc}
\hline \multirow{2}{*}{ Model } & & \multicolumn{2}{c}{ Collinearity Statistics } \\
\cline { 2 - 4 } 1 & & Tolerance & VIF \\
\cline { 2 - 4 } & & & \\
\cline { 2 - 4 } & Budaya &, 686 & 1,459 \\
\cline { 2 - 4 } & Sosial &, 606 & 1,649 \\
\cline { 2 - 4 } & Pribadi &, 519 & 1,926 \\
\cline { 2 - 4 } & Psikologi & \multicolumn{2}{c}{1,851} \\
\hline \multicolumn{2}{l}{ Sumber: Pengolahan Data, 2020 }
\end{tabular}

Berdasarkan table diatas menunjukkan bahwa nilai toleransi $>0.1$ dan nilai VIF < 10, hal ini menunjukan bahwa tidak terjadi multicolinearrity (korelasi yang tinggi) antar variabel bebas.

Model regresi yang baik adalah tidak terjadi heterokedastisitas. Untuk mendeteksi ada tidaknya heterokedastisitas dapat dilihat dengan melihat gambar Scatterplots menggunakan aplikasi SPSS. 


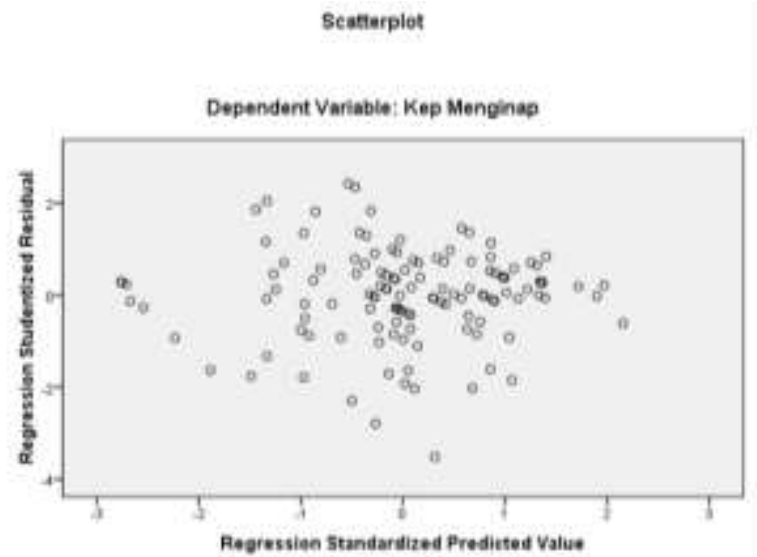

Gambar 2. Grafik Scatterplots

Berdasarkan output scatterplots diatas, dapat dilihat bahwa tidak ada pola tertentu karena titik meyebar tidak beraturan di atas dan di bawah sumbu 0 pada sumbu Y. Maka dapat disimpulkan tidak terdapat gejala heteroskedastisitas.

Selanjutnya, uji hipotesis pertama dalam penelitian ini adalah melihat pengaruh variable independent secara bersama-sama terhadap variable dependen, dengan menggunakan analisis regresi linear berganda. Hasil perhitungan dapat terlihat pada table 5 berikut:

Tabel 5. Hasil Uji F

\begin{tabular}{lllrrrr}
\hline \multicolumn{7}{c}{ ANOVA $^{\mathbf{b}}$} \\
\hline Model & \multicolumn{7}{c}{ Sum of Squares } & df & Mean Square & F & Sig. \\
\hline \multirow{2}{*}{1} & Regression & 1646,963 & 4 & 411,741 & $37,269,000^{\mathbf{a}}$ \\
\cline { 2 - 7 } & Residual & 1325,725 & 120 & 11,048 & & \\
\cline { 2 - 7 } & Total & 2972,688 & 124 & & \\
\hline
\end{tabular}

a. Predictors: (Constant), Psikologi, Budaya, Sosial, Pribadi

b. Dependent Variable: Kep Menginap

Sumber: Pengolahan Data, 2020

Dari hasil analisis regresi linear berganda dapat diketahui bahwa secara bersamasama variable independent memiliki pengaruh yang signifikan terhadap variable dependen. Hal ini dapat dibuktikan dari nilai F hitung sebesar 37.269 dengan probabilitas 0.000. Karena probabilitas jauh lebih kecil dari 0.05 maka model regresi dapat digunakan untuk mempresiksi keputusan menginap atau dapat dikatakan bahwa perubahan budaya, sosial, pribadi dan psikologis secara bersama-sama berpengaruh terhadap keputusan menginap

Hasil analisis koefisien regresi pengaruh budaya, sosial, pribadi dan psikologis terhadap keputusan menginap dapat dilihat pada table 6 berikut: 
Tabel 6. Hasil Regresi Linieritas Berganda

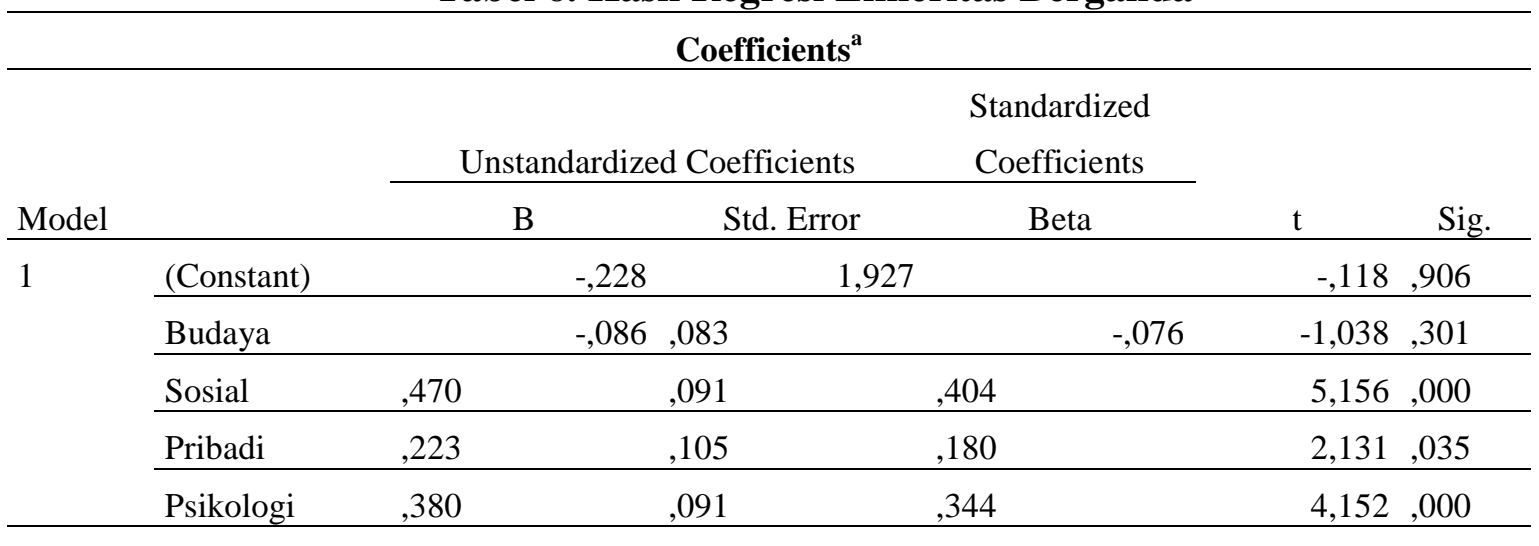

a. Dependent Variable: Kep Menginap

Sumber: Pengolahan Data, 2020

Dari hasil analisis regresi berganda diatas, tampak bahwa variabel independent yaitu social, pribadi dan psikologi berpengaruh signifikan terhadap variable dependen yaitu keputusan menginap, dengan tingkat signifikansi 0.000, 0.035 dan 0.000. Hal ini dikarenakan nilai Sig t ketiga variable independent tersebut lebih kecil dari tingkat signifikansi sebesar 0.05. Sedangkan variable budaya tidak berpengaruh signifikan signifikan karena memiliki nilai signifikan 0,301 >0,05. Dengan persamaan regresi dari hasil perhitungan statistik didapat sebagai berikut:

$$
\mathrm{Y}=-0.228-0.086 \mathrm{X} 1+0.470 \mathrm{X} 2+0.223 \mathrm{X} 3+0.380 \mathrm{X} 4+\mathrm{e}
$$

Keterangan: $\mathrm{X} 1=$ Budaya, $\mathrm{X} 2=$ Sosial, $\mathrm{X} 3=$ Pribadi, $\mathrm{X} 4=$ Psikologis, $\mathrm{Y}=$ Keputusan Menginap

Determinasi (R2) digunakan untuk melihat seberapa besar sumbangan pengaruh variabel independen (budaya, sosial, pribadi dan psikologis) terhadap variabel dependen (keputusan menginap). Sedangkan untuk melihat seberapa besar korelasi atau hubungan antara variabel dependen dengan variable independen dengan melihat nilai R. Hasil nilai $\mathrm{R}$ dan R2 terlihat pada tabel7 dibawah ini:

Tabel 7. Angka R Square

\begin{tabular}{lcccc}
\hline \multicolumn{4}{c}{ Model Summary } \\
\hline Model & $\mathrm{R}$ & R Square & $\begin{array}{c}\text { Adjusted R } \\
\text { Square }\end{array}$ & $\begin{array}{c}\text { Std. Error of the } \\
\text { Estimate }\end{array}$ \\
\hline 1 &, $744^{\mathrm{a}}$ &, 554 &, 539 & 3,32381 \\
\hline a. Predictors: (Constant), Psikologi, Budaya, Sosial, Pribadi & \\
\hline b. Dependent Variable: Kep Menginap & \\
\hline \multicolumn{3}{l}{ Sumber: Pengolahan Data, 2020 }
\end{tabular}

Dari tabel diatas dapat diketahui nilai R sebesar 0,744 menunjukkan bahwa korelasi atau hubungan antara variabel dependen (keputusan menginap) dengan variabel independen (budaya, sosial, pribadi dan psikologis) memiliki hubungan yang cukup kuat. Dari tabel diatas juga diketahui nilai Adjusted R Square untuk melihat besarnya kontribusi pengaruh variable independent secara bersama-sama pada variable dependen yaitu sebesar 
0.539. Artinya adalah sumbangan kontribusi pengaruh variabel independent terhadap variabel dependen adalah sebesar 53.9\%, sedangkan sisanya sebesar $46.1 \%$ dipengaruhi oleh variabel lain yang tidak diteliti dalam penelitian ini.

\section{Pengaruh Faktor Prilaku Konsumen (Budaya, Sosial, pribadi dan Psikologi) Terhadap keputusan tamu menginap}

Berdasarkan analisis regresi berganda, faktor budaya, sosial, pribadi dan psikologi menunjukkan pengaruh yang signifikan secara bersama-sama terhadap keputusan tamu menginap di hotel berbintang empat yang ada di kota bukitinggi, hal ini dapat dilihat pada nilai signifikansinya yang sebesar $0,000<0,05$. Untuk itu faktor-faktor prilaku konsumen harus menjadi perhatian bagi industri perhotelan di bukittinggi, khususnya hotel berbintang empat dalam upaya untuk meningkatkan tingkat hunian kamar. Hasil penelitian ini sesuai denga pendapat Kotler (2012) "faktor-faktor yang mempengaruhi tingkah laku konsumen untuk melakukan pembelian atau mengunakan suatu produk ialah faktor budaya, sosial, pribadi dan faktor psikologi”. Untuk itu para pelaku industri perhotelan khususnya di kota Bukittinggi dalam melaksanakan usaha pemasaran perlu pengarahkan sasaran pada prilaku pembelian dari konsumen.

\section{Pengaruh Faktor Budaya Terhadap keputusan tamu menginap}

Berdasarkan analisis regresi berganda, faktor budaya tidak berpengaruh signifikan terhadap keputusan tamu menginap karena memiliki nilai signifikansi sebesar 0,301 < 0,05 . Hal ini menunjukan bahwa faktor budaya dengan indikator seperti budaya, sub budaya dan kelas sosial kurang menjadi pertimbangan konsumen dalam mengambil keputusan untuk menginap di hotel berbintang empat di kota Bukittinggi.

Hasil Penelitian ini tidak sesuai dengan pendapat dari Simamora (2001) yang mengatakan "Kebudayaan adalah faktor penting dari keinginan dan perilaku seseorang yang mendasar dalam melakukan pembelian". Perbedaaan ini bisa di sebabkan oleh banyak hal, salah satunya seperti bukan merupakan kebiasaan konsumen untuk menginap di hotel berbintang empat saat melakukan sebuah perjalanan.

\section{Pengaruh Faktor sosial Terhadap keputusan tamu menginap}

Faktor sosial menunjukkan pengaruh yang signifikan terhadap keputusan tamu menginap pada hotel berbintang empat di kota Bukittinggi, ini dapat dilihat dari nilai signifikansinya yang sebesar $0,000<0,05$. Hal ini menunjukan bahwa faktor sosial dengan indikator seperti kelompok acuan, keluarga, peran dan status menjadi pertimbangan konsumen dalam mengambil keputusan untuk menginap di hotel berbintang empat di kota Bukittinggi. Saran atau anjuran yang diterima konsumen dari lingkungan sosial nya seperti teman dan keluarga menjadi pertimbangan konsumen dalam mengambil keputusan untuk menginap juga sebagai bentuk aktualisasi diri konsumen di dalam lingkungan sosialnya.

Ini sejalan dengan pendapat Lamb, hair dan Mc daniel (2001) yang mengatakan "kelompok acuan dan keluarga mempengaruhi prilaku pembelian seseorang". Kelompok acuan berfungsi sebagai titik perbandingan atau acuan langsung atau tidak langsung dalam membentuk sikap dan prilaku seseorang, "Dan keluarga institusi sosial yang paling penting bagi beberapa konsumen, karena secara kuat mempengaruhi nilai, sikap, konsep pribadi, dan prilaku pembelian ” Lamb, Hair dan Mc Daniel (2001). 


\section{Pengaruh Faktor Pribadi Terhadap keputusan tamu menginap}

Faktor pribadi menunjukkan berpengaruh secara signifikan terhadap keputusan tamu menginap pada hotel berbintang empat di kota Bukittinggi, hal ini dapat di lihat berdasarkan hasil analisis, dimana nilai signifikan faktor pribadi sebesar 0,035 < 0,05. Hal ini menunjukan faktor pribadi dengan indikator seperti usia, pekerjaan, kepribadian dan keadaan ekonomi menjadi pertimbangan konsumen dalam mengambil keputusan untuk menginap.

\section{Pengaruh Faktor Psikologi Terhadap keputusan tamu menginap}

Faktor Psikologi menunjukkan pengaruh yang signifikan terhadap keputusan tamu menginap pada hotel berbintang empat di kota Bukittinggi, ini dapat dilihat dari nilai signifikansinya yang sebesar $0,000<0,05$. Hal ini menunjukan bahwa faktor psikologi dengan indikator seperti motivasi, persepsi, pembelajaran, keyakinan dan sikap menjadi pertimbangan konsumen dalam mengambil keputusan untuk menginap di hotel berbintang empat di kota Bukittinggi. Motivasi dapat digambarkan sebagai tenaga pendorong dalam diri individu yang memaksa mereka untuk bertindak (Schifman \& Kanuk, 2008). Menurut Wulansari (2021), kualitas layanan yang sudah bagus akan membuat konsumen mempertimbangkan untuk menginap di hotel dan memegang pengaruh penting dalam membuat puasnya seorang konsumen.

\section{SIMPULAN DAN SARAN}

\section{Simpulan}

1. Faktor budaya, sosial, pribadi dan psikologi menunjukkan pengaruh yang signifikan secara bersama-sama (simultan) terhadap keputusan tamu menginap di hotel berbintang empat yang ada di Kota Bukitinggi.

2. Secara parsial faktor social, pribadi dan psikologi menunjukkan pengaruh yang signifikan terhadap keputusan tamu menginap pada hotel berbintang empat di Kota Bukittinggi.

3. Faktor sosial merupakan faktor yang paling besar pengaruhnya terhadap keputusan menginap.

4. Faktor budaya tidak berpengaruh signifikan terhadap keputusan tamu menginap di hotel berbintang empat yang ada di Kota Bukitinggi.

5. Selain itu, faktor harga dapat menjadi faktor lain yang mempengaruhi keputusan tamu untuk menginap di hotel.

\section{Saran}

Manajemen hotel perlu memperhatikan faktor-faktor yang mempengaruhi keputusan menginap yaitu faktor budaya, sosial, pribadi dan psikologis. Karena para konsumen memiliki berbagai macam pilihan hotel dengan harga serta fasilitas yang juga bervariatif. Dengan mengetahui factor perilaku konsumen tersebut, manajemen hotel akan mudah dalam menentukan langkah-langkah dan menerapkan strategi pemasaran yang tepat sehingga pada akhirnya dapat meningkatkan hunian hotel.

\section{DAFTAR PUSTAKA}

Ferdinand, Augusty. (2013). Metode Penelitian Manajemen. Semarang: Badan Penerbit Universitas Diponegoro.

Ghozali, Imam. (2016). Aplikasi Analisis Multivariate Dengan Program IBM SPSS 23. Semarang: Universitas Diponegoro 
Kotler, Philip. (2012). Dasar-dasar Manajemen Pemasaran. Edisi 2. New York: Mc Graw Hill.

Lamb, Hair dan McDaniel. (2001). Pemasaran. Buku 1. Edisi Pertama. Salemba Empat. Jakarta.

Putra, Trisna, Pasaribu, dan Nidia Wulansari. (2020). Pemasaran Wisata Berbasis Website di Nagari Wisata Harau Kabupaten Lima Puluh Kota. Jurnal Pengabdi. dan Pemberdaya. Masyarakat., vol. 2, no. 1, pp. 18-27, 2020. https://doi.org/10.24036/abdi.v2i1.34

Schiffman, Leon, L. Lazar Kanuk. (2008). Perilaku Konsumen. Alih Bahasa: Zoelkifli Kasip. Jakarta: PT. INDEKS.

Simamora, Bilson. (2001). Panduan Riset perilaku Konsumen. Jakarta: PT. Gramedia Pustaka Utama

Suryabrata, Sumadi. (2012). Metodologi Penelitian. Jakarta: PT. Raja Grafindo Persada.

Sugiyono. (2013). Metodelogi Penelitian Kuantitatif, Kualitatif Dan R\&D. Bandung: ALFABETA.

Tjiptono, Fandy. (2008). Strategi Pemasaran. Edisi 3. ANDI: Yogyakarta.

Wulansari, Nidia dan Dwi Pratiwi Wulandari. (2021). Pengaruh E-Service Quality Terhadap Kepuasan Tamu Menginap di Oyorooms Kota Bukittinggi. Ensiklopedia of Journal, Vol. 3 No.2 Edisi 2 Januari 2021. https://doi.org/10.33559/eoj.v3i2.634 